\title{
Tradisi Kemponan dan Jappe’ dalam Masyarakat Melayu Sambas Kalimantan Barat
}

\author{
Reza Akbar ${ }^{\mathrm{a}, 1, *}$, U. Sulia Sukmawati ${ }^{\mathrm{b}, 2}$
}

${ }^{a}$ Institut Agama Islam Sultan Muhammad Syafiuddin, Sambas, 79465, Indonesia

${ }^{b}$ Institut Agama Islam Sultan Muhammad Syafiuddin, Sambas, 79465, Indonesia

${ }^{1}$ reza_akbar34@yahoo.com*; ${ }^{2}$ u.suliasukmawati@gmail.com

\section{ARTICLE INFO}

Article history:

Received : 2019-01-26

Revised : 2019-04-08

Accepted : 2019-05-28

Keywords:

Kemponan

Jappe'

Sambas Malay

Kata Kunci:

Kemponan

Jappe'

Melayu Sambas

\section{ABSTRACT}

The people of Sambas Regency recognize the Kemponan belief. It is the belief about a disaster that can occur to someone if they reject the food or drink offered without tasting the food known as Jappe'. This study is to identify the Kemponan tradition and Jappe spreading out at the people of Sambas Malay. This study is qualitative field research using data collection methods through in-depth interviews. Dealing with the Kemponan and Jappe 'traditions, the Sambas Malay people is divided into four groups; those who believe and carry out both traditions, those who doubt the Kemponan and continue to carry out the Jappe' tradition, those who do not believe in the existence of Kemponan but still carry out the Jappe' tradition, and those who have left the two traditions. The Kemponan and Jappe ' traditions viewed from a sharia perspective were that, first, it was allowed if Kemponan was only interpreted as a desire that was not conveyed and was not associated with the existence of magical power. Second, it was forbidden if it was believed that certain foods have the pulling power of the Kemponan and Jappe' and it was done to avoid calamity.

\section{ABSTRAK}

Masyarakat di Kabupaten Sambas, mengenal kepercayaan kemponan yaitu kepercayaan tentang adanya malapetaka yang dapat menimpa seseorang jika menolak makanan atau minuman yang ditawarkan tanpa mencicipi makanan tersebut yang dikenal dengan istilah jappe'. Penelitian ini bertujuan untuk mengidentifikasi tradisi kemponan dan jappe' yang berkembang di kalangan masyarakat Melayu Sambas. Penelitian ini merupakan penelitian kualitatif lapangan menggunakan metode pengambilan data melalui wawancara secara mendalam. Dalam pelaksanaan tradisi kemponan dan jappe', masyarakat Melayu Sambas terbagi ke dalam empat kelompok; mereka yang percaya dan melaksanakan kedua tradisi tersebut, mereka yang ragu terhadap kemponan dan tetap melaksanakan tradisi jappe', mereka yang tidak percaya adanya kemponan namun tetap melaksanakan tradisi jappe', dan mereka yang telah meninggalkan kedua tradisi tersebut. Adapun tradisi kemponan dan jappe' ditinjau dari perspektif syariah adalah Pertama, hukumnya boleh jika kemponan hanya diartikan sebagai hasrat yang tidak tersampaikan dan tidak dikaitkan dengan adanya kekuatan magis. Kedua, hukumnya haram apabila meyakini makanan tertentu memiliki kekuatan penarik terjadinya kemponan serta jappe' dilakukan karena ingin terhindar dari malapetaka.

Copyright (C) 2019 IAIN Palangka Raya. All rights reserved.

\section{Pendahuluan}

Melayu (Malay) merupakan salah satu suku yang memiliki pengaruh yang sangat besar dalam khasanah kebudayaan bangsa
Indonesia dan juga bangsa-bangsa lain di dunia. Pengaruhnya sangat menonjol terutama bahasanya yang digunakan secara luas di Nusantara dan negara-negara rumpun 
Melayu. Menurut persebarannya, bahasa Melayu mencakup wilayah geografis yang sangat luas dan dipergunakan sebagai perekam sejarah, pencatatan undang-undang, pengucapan dan penulisan perjanjian, dan bahasa ini juga menjadi bahasa dakwah oleh berbagai agama dan kepercayaan sepanjang perjalanan peradaban Melayu di Nusantara.(29) Pengaruhnya secara nyata dibuktikan dengan sebagian besar bahasanya yang diadopsi sebagai bahasa Indonesia yang kemudian menjadi bahasa nasional dan bahasa pemersatu. Negara-negara tetangga seperti Malaysia, Brunei Darussalam, dan Singapura juga menggunakan bahasa Melayu sebagai salah satu bahasa pengantar negara. Di Indonesia, sebagian besar suku Melayu menempati wilayah yang cukup luas meliputi Pulau Kalimantan dan Sumatera. Dengan demikian, muncullah beberapa kelompok suku Melayu yang dikenal hingga saat ini seperti Melayu Tamiang, Melayu Palembang, Melayu Bangka-Belitung, Melayu Deli, Melayu Riau, Melayu Jambi, Melayu Bengkulu, Melayu Pontianak Dan Melayu Sambas.

Salah satu wilayah di Kalimantan Barat yang sebagian besar masyarakatnya merupakan keturunan suku Melayu adalah Kabupaten Sambas. Kabupaten ini sudah terbentuk sejak tahun 1960 dan mengalami pemekaran menjadi tiga kabupaten dan kota yaitu Kabupaten Bengkayang, Kota Singkawang, dan Kabupaten Sambas.(12) Di Kabupaten Sambas ini, terdapat warisan kebudayaan Kerajaan Islam Melayu yang masih terjaga yaitu berupa Keraton yang awalnya sudah dibangun pada tahun 1632 yang kemudian dibangun kembali pada tahun 1933.(30) Di dekat keraton tersebut terdapat Masjid Jami' yang dibangun oleh Sultan Umar Aqomuddin (memerintah tahun 17021727) yang kemudian direnovasi oleh puteranya pada tahun 1885. Di depan Masjid yang terletak di Muara Ulakan Sungai Sambas ini terdapat sebuah tulisan yang sangat terkenal sebagai simbol Masjid Keraton yang ditulis dalam bahasa Arab "alwâtsiqu billâh" yang berarti orang yang percaya teguh dengan Allah. Keraton dan Masjid ini menjadi daya tarik bagi wisatawan, baik dari dalam maupun luar Kabupaten Sambas.
Masyarakat Melayu khususnya Kabupaten Sambas identik dengan Islam. Boleh dikatakan bahwa hampir seluruh masyarakat Melayu Sambas beragama Islam.(12) Identitas ini tidak seperti suku-suku lain seperti Dayak, Jawa, dan Batak yang tidak membawa label agama tertentu dalam kesukuan mereka. Budaya Masyarakat Melayu Sambas yang benafaskan Islam tergambar dalam beberapa tradisinya seperti tepung tawar, kesenian islami nyerakal, tulisan Arab Melayu, seni tari raddat, dan lain-lain. Dengan demikian, kajian tentang budaya Melayu Kabupaten Sambas sangat erat kaitannya dengan budaya-budaya Islam yang memengaruhinya. Hal tersebut memberikan isyarat bahwa Islam yang dibawa oleh para ulama pembaharu dalam nuansa keislaman tidak hanya dalam bidang politik, akan tetapi juga merambah dalam bidang sosial budaya masyarakat.(22)

Di dalam masyarakat Kalimantan Barat, khususnya Kabupaten Sambas, berkembang kepercayaan masyarakat mengenai kemponan yaitu kepercayaan tentang adanya malapetaka (kejadian buruk) yang dapat menimpa seseorang jika menolak makanan atau minuman yang ditawarkan tanpa mencicipi atau menyentuh makanan tersebut, yang dikenal dengan istilah jappe'. Keyakinan ini telah menjadi kebiasaan bagi segelintir orang-orang Melayu di Kabupaten Sambas. Ada yang memang meyakini dan ada pula yang masih melaksanakan tradisi jappe' ini sekadar menghargai pemberian dengan maksud tidak menyinggung perasaaan orang yang menawarkan makanan.

Pada dasarnya, kemponan dan jappe' ini memiliki kemiripan dengan istilah pamali yang berkembang di beberapa daerah di Indonesia. Akan tetapi, istilah pamali masih bersifat umum karena merupakan aturan yang tabu (umumnya bersifat larangan), namun masih diyakini oleh masyarakat. Misalnya sebuah penelitian yang dilakukan oleh Widiastuti di Kabupaten Kuningan. Penelitian yang menggunakan pendekatan semiotika dan etnopedagogi ini menghasilkan kategorisasi macam pamali, nilai edukatifnya seperti sistem religi, ilmu pengetahuan, sosial, dan lain-lain.(26) Sedangkan istilah kemponan dan jappe' yang dikenal di kalangan masyarakat Melayu Sambas 
merupakan istilah khusus yang memiliki makna tersendiri.

Tradisi kemponan dan jappe' di kalangan masyarakat Melayu Sambas ini memang sudah diungkap oleh Mustansyir. Penelitian yang menggunakan pendekatan filosofis tersebut membagi masyarakat ke dalam dua kelompok; pertama, masyarakat yang menganggap kemponan memiliki arti dan nilai penting bagi kehidupan masyarakat dan kedua, masyarakat yang sudah mulai meninggalkannya karena memudar akibat perubahan zaman.(12) Penelitian tersebut tidak mengkaji tradisi kemponan dan jappe' melalui pendekatan normatif berdasarkan pandangan syariah. Kajian syariah mengenai hal ini sangat penting dilakukan karena bagaimana pun, suatu tradisi tidak boleh bertentangan dengan ajaran Islam agar keduanya dapat berjalan selaras.

Selain itu, tradisi kemponan pada masyarakat Kalimantan Barat juga sudah dilakukan oleh Nindwihapsari melalui pendekatan deskriptif kualitatif. Hasilnya adalah makna dan struktur kemponan yang terdiri atas tanda (pengabaian tawaran makanan/minuman), akibat (situasi marabahaya), dan konversi (penghindaran marabahaya).(14) Penelitian ini berfokus pada memaknai arti kemponan, tidak menelaah penerapannya di kalangan masyarakat. Penelitian ini juga tidak mengkaji tradisi kemponan dalam pandangan syariah.

Terlepas dari tradisi dan budaya apa pun dan mana pun, Islam hakikatnya menghendaki pengikutnya untuk menyerahkan sepenuhnya kehidupan manusia kepada Allah dalam bentuk kemantapan akidah, tanpa ada percampuran dengan hal-hal yang dapat membatalkan syahadat. Kemponan sebagai sebuah kepercayaan yang tidak dikenal di dalam Islam, patut ditelaah terutama dari sudut pandang syariah. Kajian syariah menempati urutan yang sangat penting karena berkaitan dengan akidah seorang muslim. Kajian ini juga diharapkan memperjelas status keyakinan terhadap tradisi kemponan dan jappe' yang berkembang dalam masyarakat Melayu Sambas, apakah termasuk tahayul yang dapat merusak akidah atau hanya sekedar warisan budaya atau tradisi. Oleh sebab itu, penelitian ini menjadi semakin penting untuk dilakukan.

\section{Tinjauan Pustaka}

\section{a. Mengenal Masyarakat Melayu Sambas}

Dilihat dari letak geografisnya, Kabupaten Sambas terletak di wilayah $1^{\circ} 23^{\prime \prime}$ LU dan $108^{\circ} 39^{\prime \prime}$ BT dengan batas administratif: sebelah utara berbatasan dengan Malaysia Timur (Sarawak) dan Laut Natuna, sebelah selatan berbatasan dengan Kabupaten Bengkayang dan Kota Singkawang, sebelah timur berbatasan dengan Kabupaten Bengkayang dan Serawak, dan sebelah barat berbatasan dengan Laut Natuna. Wilayah administratif Sambas meliputi 19 Kecamatan yaitu Kecamatan Sambas, Kecamatan Sebawi, Kecamatan Tebas, Kecamatan Semparuk, Kecamatan Pemangkat, Kecamatan Salatiga, Kecamatan Selakau, Kecamatan Selakau Timur, Kecamatan Tekarang, Kecamatan Jawai, Kecamatan Jawai Selatan, Kecamatan Sajad, Kecamatan Sejangkung, Kecamatan Paloh, Kecamatan Teluk Keramat, Kecamatan Tangaran, Kecamatan Subah, dan Kecamatan Sajingan Besar dengan desa keseluruhan berjumlah 184 desa.(31)

Orang-orang Melayu pada awalnya merupakan orang-orang yang tinggal di pedesaan, bekerja sebagai nelayan, berkebun, dan bertani. Mereka sejak dulu beragama Islam dan adat istiadatnya sedikit atau pun banyak juga diwarnai oleh Islam.(6) Pengaruh Islam (Arab) terhadap masyarakat Melayu lebih dominan dibandingkan dengan pengaruh bangsa-bangsa lain (seperti India dan China) sehingga muncul istilah "Dunia Melayu Dunia Islam". Sintesa kebudayaan Melayu dan Islam dapat dilihat melalui ungkapan "Adat bersendi syarak, syarak bersendikan kitabullah" di daerah-daerah seperti Aceh, Minangkabau, Riau, Jambi, Palembang, Banjar, Bugis, Gorontalo, Ternate, dan sebagainya. Bagi masyarakat di daerah-daerah tersebut, menjadi Melayu berarti Menjadi Islam.(18)

Menurut Effendy masyarakat Melayu Sambas adalah mereka yang berkomunikasi menggunakan bahasa Melayu, hidup dalam tradisi Melayu, beragama Islam, dan bertempat tinggal di wilayah Sambas. Bahasa Melayu Sambas adalah bahasa Melayu 
berdialek Sambas yang dituturkan di Kabupaten Sambas, Kota Singkawang, Kabupaten Bengkayang dan sekitarnya. Namun demikian, bahasa Melayu Sambas antara komunitas (katakanlah desa) yang satu dengan komunitas yang lain terdapat perbedaan, terutama dalam hal dialek.(12)

Secara historis, suku Melayu Sambas merupakan bagian dari rumpun suku Dayak, khususnya Dayak Melayik. Hal ini didasarkan pada identitas Dayak yang digunakan orang-orang pribumi (Melayu) pada masa itu untuk bangkit dari keadaan yang disebut terpinggirkan (marginal).(28) Selain itu terdapat adanya hubungan antara bahasa Melayik dan bahasa Melayu di Kalimantan Barat yakni memiliki satu akar yang sama, satu rahim budaya yang sama, satu asal-usul, sebelum akhirnya menjadi bahasa yang dikenal saat ini. Tentunya hal itu sudah mengalami berbagai peristiwa adaptasi dan evolusi bunyi, dialek, irama, dan lain sebagainya yang kemudian disebut sebagai proses pembentukan bahasa.(12)

Pada masa Kesultanan Sambas, masyarakat Melayu Sambas terkenal agamis sehingga sempat disebut sebagai Serambi Makkah Kalimantan Barat. Pada masa itu, ulama-ulama Islam dari Kesultanan Sambas sangat terkemuka dan telah berkaliber internasional, misalnya pada abad ke-19 M ada seorang ulama Kesultanan Sambas yang bernama Sheikh Khatib Achmad As-Sambasi yang menjadi ulama di Makkah dan menjadi pemimpin ulama-ulama di Nusantara yang menuntut ilmu agama di sana dengan gelar Shekh Sharif Kamil Mukammil. Kemudian pada abad ke-20 M, ada pula ulama Kesultanan Sambas yang bernama Shekh Muhammad Basuni Imran yang merupakan lulusan Al-Azhar Kairo, Mesir yang terkenal di Timur Tengah karena suratnya kepada Mufti Mesir yang berjudul Mengapa Umat Islam saat ini Mengalami Kemunduran?(17)

\section{b. Tradisi Kemponan dan Jappe'}

Tradisi kemponan adalah kepercayaan orang-orang zaman dulu dan tidak diketahui bagaimana kemunculannya. Tradisi kemponan dalam masyarakat Melayu Sambas erat kaitannya dengan kejadian buruk akibat menolak tawaran makanan tanpa mencicipinya. Di beberapa daerah, tradisi kemponan ini juga berkembang dengan sebutan yang berbeda-beda. Di kalangan suku Sasak (Lombok), dikenal istilah tularmenuh yaitu kepercayaan segelintir masyarakat mengenai adanya malapetaka atau kejadian buruk karena menolak makanan, apalagi bagi mereka yang akan bepergian jauh.(19) Sedangkan di Makassar, berkembang pula kepercayaan ini di kalangan masyarakatnya yang merupakan bagian dari pamali. Adapun di kalangan orang-orang Jawa dan Sumatera, hal semacam ini tidak pernah dikenal. Di kalangan orang-orang Jawa, menerima pemberian makanan yang sudah dihidangkan oleh tuan rumah hanya sebatas bermakna adab dalam bertamu sehingga tuan rumah merasa senang.(25)

Kemponan yang diyakini oleh segelintir masyarakat Melayu Sambas ini sebenarnya tergolong ke dalam takhayul karena tradisi ini pada dasarnya adalah kepercayaan kepada sesuatu yang dianggap ada atau sakti, tetapi sebenarnya tidak ada atau tidak sakti. Kepercayaan tersebut sebenarnya adalah larangan untuk menolak pemberian makanan atau minuman yang pada hakikatnya bagian dari pengertian takhayul. Bagi kalangan yang percaya, kemponan ini dapat dicegah dengan berbagai sikap atau respon seperti menerima pemberian, mencicipi sedikit, atau sekedar menyentuhkan tangan pada makanan/minuman yang ditawarkan yang dikenal dengan istilah jappe'. Jadi, tradisi jappe' dalam masyarakat Melayu Sambas Kalimantan Barat adalah kesediaan menerima pemberian makanan/minuman tetapi dengan cara mencicipi sedikit atau hanya menyentuh makanan/minuman yang ditawarkan seseorang. Istilah jappe' ini terkadang dikenal dengan istilah cappe' atau japai. Ada juga yang menyebutnya dengan istilah jama' (jamah). Orang-orang Sajingan khususnya orang-orang tua ada yang menyebutnya dengan istilah gowu.(4)

Jappe' ternyata bukan satu-satunya cara untuk melepaskan diri dari kemponan. Moni (19 tahun) pemuda asal Desa Kubangga mengutarakan bahwa selain jappe', orangorang biasanya melakukan tradisi menyebut 
suatu perkataan "aek liurku lebih nyaman daripade makanan tadek" yang berarti "Air liur saya lebih enak daripada makan tadi". Hal ini ia lakukan apabila jappe' tidak dilakukan karena suatu sebab seperti terlupa, tidak punya waktu (dalam keadaan terburuburu) dan lain-lain. Perkataan tadi ia yakini dapat menggantikan jappe' sehingga dapat menghindarkan diri dari kemponan.(11)

Lain lagi menurut "Nr" (19 tahun) yang berasal dari Desa Kartiasa. Selain jappe', untuk menghindarkan diri dari kemponan dapat dilakukan dengan cara menunjuk (dengan jari) makanan yang diinginkan (ditawarkan) dengan jari telunjuk, kemudian jari tadi disentuhkan ke lidah. Ini merupakan tradisi segelintir orang-orang di desanya sebagai pengganti tradisi jappe' untuk menghindarkan diri dari terjadinya kemponan.(15)

\section{Metode Penelitian}

Penelitian ini merupakan penelitian kualitatif lapangan yang termasuk ke dalam jenis penelitian etnografi yaitu salah satu jenis penelitian kualitatif yang melakukan studi terhadap budaya kelompok dalam kondisi yang alamiah melalui observasi dan wawancara.(24) Budaya yang dimaksud di dalam penelitian ini adalah sebuah tradisi berupa tindakan dan keyakinan masyarakat Melayu Sambas dalam menjalankan tradisi kemponan dan jappe'. Penelitian ini menggunakan metode pengambilan data melalui wawancara (interview) secara mendalam tentang tradisi kemponan meliputi pandangan informan terhadap tradisi kemponan, penerapannya, dan nilai-nilai di balik tradisi tersebut. Teknik sampling yang digunakan adalah purposive sampling yakni peneliti menentukan sendiri sampel yang diambil karena ada pertimbangan tertentu. Selanjutnya, data dianalisis dengan beberapa pendekatan; pertama adalah pendekatan induktif yaitu berupa kegiatan menghasilkan kategori, klasifikasi, atau tipologi data.(1) Hasilnya adalah kategorisasi masyarakat Melayu Sambas dalam menerapkan tradisi kemponan dan jappe'. Kedua, metode analisis dengan pendekatan normatif yaitu mendeskripsikan tradisi kemponan dan jappe' dalam masyarakat Melayu Sambas Kalimantan Barat dari sudut pandang syariah berdasarkan pandangan pihak yang berkompeten.

\section{Hasil dan Diskusi}

\section{a. Kepercayaan Masyarakat Melayu Sambas Kalimantan Barat terhadap Tradisi Kemponan dan Jappe'}

Kemponan merupakan sebuah kepercayaan orang-orang Melayu Sambas Kalimantan Barat mengenai kecelakaan yang disebabkan karena tidak mencicipi makanan yang ditawarkanorang lain kepadanya. Masih eksisnya kepercayaan terhadap adanya kemponan dalam masyarakat Melayu Sambas Kalimantan Barat hingga saat ini disebabkan karena faktor ajaran yang turun-temurun sehingga terus diajarkan oleh para orang tua kepada anak-cucu mereka. Menurut Kamal (61 tahun), yang merupakan salah satu tokoh masyarakat Suku Melayu Sambas asal Kecamatan Jawai, asal-muasal tradisi kemponan dan jappe' ini memang tidak diketahui dengan jelas, bukan pula berasal dari cerita rakyat Batu Ballah(10) yang mengisahkan seorang ibu yang ditelan batu karena makananannya dihabiskan oleh anaknya. Hingga saat ini, baik kalangan anak muda maupun orang-orang tua, kemponan masih menjadi tradisi yang sulit ditinggalkan.

Dalam konteks penerapan tradisi kemponan, Mustansyir mengelompokkan masyarakat Kabupaten Sambas Kalimantan Barat ke dalam dua golongan. Pertama, kelompok yang berpendirian bahwa kemponan sebagai pengada sungguh memiliki arti dan nilai penting dalam kehidupan mereka. Kedua, kelompok yang memandang bahwa kemponan sebagai pengada sudah memudar arti dan nilainya.(12) Namun, disebabkan kemponan dan jappe' merupakan tradisi yang tidak dapat dipisahkan, di dalam penelitian ini, penulis mengelompokkan masyarakat Melayu Sambas Kalimantan Barat menjadi empat kelompok yakni dalam menjalankan tradisi kemponan dan jappe':

\section{Masyarakat yang meyakini tradisi kemponan dan jappe'}

Di antara pemuda Melayu Sambas, adalah "Yn" (21 tahun) asal Kampong Lorong yang menuturkan bahwa kemponan adalah benar adanya. Menurutnya pantang menolak 
tawaran makanan atau minuman, terlebih jika yang disuguhkan adalah air kopi. Apabila menolak tawaran makanan atau minuman sementara tidak punya waktu cukup untuk menyantapnya, dia meyakini bahwa akan terjadi kemponan. Adapun agar terhindar dari hal tersebut, seseorang harus jappe'. Keyakinan tersebut dikuatkan dengan menceritakan pengalaman pribadinya yakni kecelakaan yang dialaminya pada tahun 2013 di desanya Kampong Lorong, Kabupaten Sambas. Sebelum terjatuh dari sepeda motor, dirinya ditawari air kopi oleh ibunya. Setelah beberapa saat, dia lupa untuk jappe'. lalu meyakini bahwa kecelakaan yang menimpanya disebabkan karena menolak tawaran air kopi tersebut dan lupa untuk jappe'. Orang-orang Melayu Sambas yang meyakini kemponan, sangat pantang menolak tawaran makanan atau minuman, terutama air kopi.(27)

Pemuda lain "Gr" (23 tahun) juga termasuk orang yang meyakini adanya kemponan. Keyakinannya itu dikuatkan dengan kejadian yang menimpanya bersama ayahnya ketika sedang melakukan perjalanan ke Kota Tebas menggunakan sepeda motor pada tanggal 3 Desember 2018 di Desa Rambi. Sebelum berangkat, ibunya menawarkan air kopi kepada mereka. Karena terburu-buru, mereka tidak sempat mencicipi (tidak jappe'). Di dalam perjalanan, mereka menabrak trotoar karena menghindari mobil yang membawa material bangunan yang menyebabkan tulang ayahnya patah di bagian leher. Kecelakaan yang menimpa mereka itu diyakininya sebagai kemponan karena menolak tawaran air kopi dan tidak jappe'.(7)

Kemudian juga "El" (38 tahun) asal Desa Sungai Pinang yang yakin terhadap kemponan apabila yang ditawarkan berupa nasi jika tidak jappe'. Adapun selain nasi, dirinya berkeyakinan tidak terjadi kemponan sehingga dirinya tidak perlu jappe'. Menolak tawaran makanan berupa nasi ini menjadi pantangan yang diyakini berasal dari ajaran orangtuanya dan terus disampaikan kepada anaknya.(5)

\section{Masyarakat yang ragu-ragu terhadap tradisi kemponan dan jappe'}

Ada pula masyarakat yang ragu-ragu mengenai kebenaran kemponan. "Sp" (20 tahun) dari Desa Kubangga Kabupaten Sambas menuturkan bahwa kemponan memang diajarkan secara turun-temurun dari keluarga. Kemponan menurutnya seperti sesuatu yang sulit dipercaya, namun terjadi secara nyata. dirinya menuturkan pengalamannya sendiri beberapa tahun yang lalu tentang kemponan yang disebabkan pernah menolak tawaran air kopi dari neneknya. Adapun kejadian yang menimpanya waktu itu adalah terjatuh karena tidak jappe'.(23)

Pemuda lain "Ar" (21 tahun) dari Desa Trengguli Kabupaten Sambas yang termasuk orang yang meragukan kebenaran kemponan. Secara pribadi, dirinya belum pernah mengalaminya dan sekedar mendengar cerita dari keluarga dan orang-orang. Hanya saja, keluarganya memang percaya kebenaran kemponan. Menurutnya, jappe' tetap menjadi tradisi untuk mencegah kemponan. Baginya, jappe' memberikan efek tenang dan merupakan upaya mencari aman dari kemponan.(2)

"As" (51 tahun) dari Desa Sari Makmur Kecamatan Tekarang juga termasuk orang yang ragu-ragu terhadap kemponan. dirinya menuturkan bahwa memang tidak melaksanakan tradisi ini secara pribadi dan tidak pula mengajarkan tradisi tersebut kepada anak-anaknya. Namun, ketika ditawari makanan dan orang yang menawarkan mengatakan "ayo dimakan, nanti kemponan" muncul rasa kawatir dalam hatinya sehingga harus menerima tawaran tersebut semisal mencicipi sedikit atau sekedar jappe'. Padahal dirinya belum pernah memiliki pengalaman selama hidupnya mengenai kemponan akibat menolak makanan atau minuman yang ditawarkan.(3)

\section{Masyarakat yang meninggalkan tradisi kemponan dan jappe' sebagian}

Kelompok ketiga ini adalah orang-orang yang tidak percaya terhadap kemponan, namun tetap melaksanakan tradisi jappe'. Tujuannya adalah sekedar melaksanakan adat. Maksudnya, ketika mereka ditawarkan makanan, mereka tetap jappe' karena ingin menghargai pemberian sehingga orang yang 
menawarkan makanan tidak kecewa atau berkecil hati. "Re" (20 tahun) asal Desa Matang Danau adalah salah seorang remaja yang tidak percaya adanya kemponan, namun tetap melakukan tradisi jappe' karena ingin menghargai pemberian.(21)

"Nn" (35 tahun) asal Kecamatan Sejangkung juga termasuk orang Melayu Sambas yang tidak meyakini adanya kemponan, akan tetapi ketika menawarkan makanan kepada anaknya, dirinya masih menyebutkan "makan dulu, nanti kemponan". Perkataan tersebut sering diucapkan, namun hanya sebatas kebiasaan yang sebenarnya tidak diyakini. Selain itu, untuk menghargai pemberian orang lain, dirinya masih melaksanakan tradisi jappe'.(13)

\section{Masyarakat yang meninggalkan tradisi kemponan dan jappe' secara total}

Kelompok ini tidak percaya sama sekali adanya kemponan dan tidak pula melaksanakan tradisi jappe' ketika ditawarkan makanan karena menganggap hal tersebut hanya sebuah tahayul. "Nr" (20 tahun) asal Desa Semparuk menuturkan bahwa memang tidak memercayai kemponan dan tidak melaksanakan jappe' sebagai tradisi. Padahal, di keluarganya yakni ibu dan neneknya masih memegang teguh tradisi kemponan dan jappe'. Alasan untuk meninggalkan tradisi tersebut adalah karena memandang bahwa hal tersebut merupakan tahayul yang dapat mengakibatkan seseorang terbawa kepada dosa syirik. Selain itu, tradisi ini adalah tidak rasional karena tidak ada makanan atau minuman yang memiliki kekuatan magis untuk dapat mencelakakan manusia.(16)

Pemuda lain yang juga meninggalkan tradisi kemponan dan jappe' adalah "In" (22 tahun) remaja asal Desa Tengguli. Menurutnya, tradisi tersebut memang sulit dihilangkan dan terus diajarkan secara turuntemurun, termasuk di dalam keluarganya. Dirinya yakin bahwa segala musibah datang atas izin Allah dan tidak berhubungan dengan kemponan karena tidak melakukan jappe'.
Menurutnya juga bahwa musibah merupakan bentuk ujian dan takdir Allah yang tidak dapat dihindarkan.(9)

\section{b. Pandangan Syariah terhadap Kemponan dan Jappe'}

Tradisi kemponan dan jappe' dalam masyarakat Melayu Sambas memang masih hidup (living tradition), walaupun terdapat pula masyarakat yang sudah meninggalkan tradisi tersebut dengan berbagai alasan seperti faktor modernitas, faktor tidak rasional, dan faktor kontroversi terhadap ajaran Islam. Namun, tidak sedikit pula masyarakat yang masih berpegang teguh pada tradisi ini yang memang sudah jelas bukan berasal dari ajaran Islam. Islam hanya mengajarkan kepada pengikutnya menerima pemberian, terlebih apabila pemberian tersebut merupakan sesuatu yang bermanfaat. Di antara masyarakat Melayu Sambas, bahkan ada yang menganggap air kopi memiliki penarik yang kuat akan terjadinya kemponan apabila ditolak atau tidak jappe'. Sedangkan makanan lainnya, masyarakat Melayu Sambas memiliki pandangan yang bermacam-macam. Hal ini seolah-olah makanan tertentu jika ditolak (pemberiannya) memiliki kekuatan magis sehingga dapat menyebabkan kemponan. Menanggapi fenomena ini, ayat Al-Quran berikut ini merupakan penegasan bahwa segala sesuatu yang terjadi ialah atas kehendak Allah, bahkan Rasulullah sendiri tidak dapat menyebabkan sesuatu hal terjadi baik menarik kemanfaatan maupun menolak kemudharatan kecuali atas izin Allah.(20)

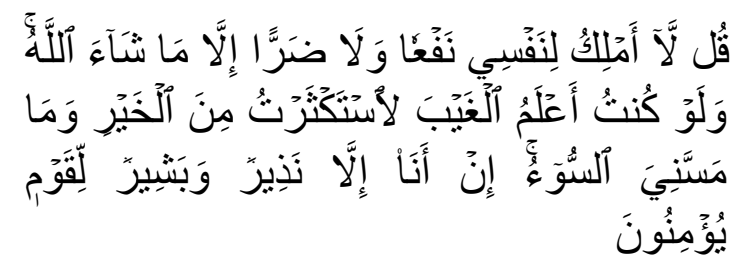

Artinya: Katakanlah: "Aku tidak berkuasa menarik kemanfaatan bagi diriku dan tidak (pula) menolak kemudharatan kecuali yang dikehendaki Allah. dan Sekiranya aku mengetahui yang ghaib, tentulah aku membuat kebajikan sebanyak-banyaknya dan aku tidak akan ditimpa kemudharatan. aku tidak lain hanyalah pemberi peringatan, dan 
pembawa berita gembira bagi orang-orang yang beriman" (Q.S. Al-A'râf [7]:188).

Menurut "Hf" (salah satu dai terkemuka di Kalimantan Barat), untuk menghukumi tradisi kemponan dan jappe', perlu didefiniskan terlebih dahulu makna keduanya. Jika tradisi kemponan diyakini sebagai sebuah bala atau kejadian buruk yang dapat timbul akibat menolak tawaran makanan atau minuman (khususnya air kopi dan nasi yang menurut segelintir orang-orang Sambas pantang untuk ditolak kecuali melakukan jappe') dan tidak jappe' serta kejadiannya bukan sebagai kehendak Allah maka hal ini dapat mengakibatkan rusaknya akidah seseorang. Dengan kata lain, apabila jappe' diyakini sebagai wasilah (sarana) untuk menghindari kejadian buruk yang dapat menimpa seseorang maka orang tersebut telah jatuh ke dalam dosa syirik atau menyekutukan Allah. Namun, apabila jappe' tersebut dilakukan semata-mata untuk menghargai pemberian orang lain atau sekedar tradisi, hal ini tidaklah menyebabkan kerusakan akidah seseorang karena tidak ada niat untuk menghindari sebuah bala melalui jappe' tersebut. Dengan demikian, faktor niat (hati) menjadi penentu apakah tradisi kemponan dan jappe' bertentangan atau tidak terhadap ajaran Islam.(8)

Tradisi kemponan dan jappe' tidak akan membawa seseorang kepada dosa syirik apabila keduanya tidak dikaitkan dengan konteks akidah. Misalnya, kemponan yang dialami seseorang disebabkan karena sebelumnya menolak makanan atau minuman sehingga menyebabkan seseorang lapar, ngantuk, atau tidak fokus dalam beraktifitas (berkendara dan lain-lain). Dengan demikian, jappe' yang dilakukan bukan semata-mata karena ingin selamat dari mara bahaya, melainkan sebagai pengganti hasrat makan/minum sehingga tidak lagi memikirkan tawaran makanan.minuman yang ditolak sebelumnya. "Yn" (20 tahun) asal Tanjung Rasau adalah salah seorang pemuda yang menganggap kejadian kemponan hanya disebabkan seseorang tidak fokus dalam beraktifitas sebagai akibat tidak terpenuhinya hasrat makan atau minum yang ditawarkan kepadanya.

Menurut "Nr" (20 tahun) asal Semparuk, perbedaan pandangan terhadap tradisi kemponan pernah menjadi penyebab perselisihan pendapat di antara anggota keluarganya yaitu antara saudara dan neneknya. Orang-orang tua umumnya sangat patuh terhadap tradisi secara turun-temurun. Sedangkan anak-anak muda pola pikirnya lebih mudah terbuka karena memiliki peluang mengenyam pendidikan yang tinggi. Dengan demikian, jika terdapat perbedaan pendapat antara kaum muda dan kaum tua, sekalipun dalam masalah yang mendasar maka penyelesaiannya adalah mengembalikan persoalan tersebut kepada Al-Quran. Allah berfirman:

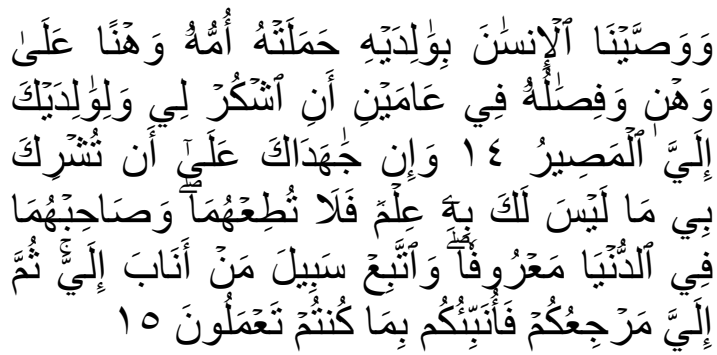

Artinya: 14. Dan Kami perintahkan kepada manusia (berbuat baik) kepada dua orang ibu- bapanya; ibunya telah mengandungnya dalam Keadaan lemah yang bertambahtambah, dan menyapihnya dalam dua tahun.Bersyukurlah kepadaku dan kepada dua orang ibu bapakmu, hanya kepadaKulah kembalimu. 15. Dan jika keduanya memaksamu untuk mempersekutukan dengan aku sesuatu yang tidak ada pengetahuanmu tentang itu, Maka janganlah kamu mengikuti keduanya, dan pergaulilah keduanya di dunia dengan baik, dan ikutilah jalan orang yang kembali kepada-Ku, kemudian hanya kepada-Kulah kembalimu, Maka Kuberitakan kepadamu apa yang telah kamu kerjakan (Q.S. Luqman [31]:14-15).

Ayat di atas menjelaskan bahwa berbakti kepada kedua orang tua adalah wajib bagi setiap anak. Akan tetapi, anak tidak wajib taat kepada orang tua kecuali dalam kebajikan. Dalam konteks tradisi kemponan dan jappe', anak tidak wajib taat atau mengikuti tradisi apabila hal tersebut merusak akidah. Sedangkan makna dari 
pergaulilah keduanya di dunia dengan baik dalam konteks perbedaan pendapat antara kaum muda dan tua dalam persoalan tradisi seperti kemponan dan jappe' dalam masyarakat Melayu Sambas Kalimantan Barat menurut Hifni antara lain: Pertama, mengajak kaum tua untuk terus belajar seperti mengikuti kajian-kajian atau majelis taklim khususnya dalam persoalan akidah. Kedua, tetap menghormati tradisi yang berlaku di masyarakat dan mengembangkan sikap kritis terhadap tradisi yang tidak sesuai dengan syariat Islam.(8) Dengan demikian, perbedaan pandangan terhadap tradisi tidak sepantasnya merenggangkan hubungan antar sesama muslim, terutama antara orang tua dan anak.

\section{Kesimpulan}

Masyarakat Melayu Sambas Kalimantan Barat dalam konteks tradisi kemponan dan jappe' terbagi menjadi empat golongan yaitu: Pertama, masyarakat yang meyakini dan melaksanakan tradisi kemponan dan jappe'. Kedua, masyarakat yang ragu-ragu terhadap kemponan dan tetap melaksanakan tradisi jappe'. Ketiga, masyarakat yang tidak meyakini kemponan, akan tetapi masih melaksanakan tradisi jappe' dikarenakan ingin menghargai pemberian, dan Keempat, masyarakat yang meninggalkan tradisi kemponan dan jappe' secara total.

Adapun tradisi kemponan dan jappe' ditinjau dari perspektif syariah adalah Pertama, hukumnya boleh jika kemponan hanya diartikan sebagai hasrat yang tidak tersampaikan dan tidak dikaitkan dengan adanya kekuatan magis yang dimiliki oleh makanan tertentu jika tidak jappe'. Selain itu, pelaksanaan tradisi jappe' boleh dilakukan apabila sekadar menjalankan adat istiadat atau berniat menghormati pemberian orang lain. Kedua, hukumnya haram atau jatuh pada dosa syirik apabila menganggap makanan yang ditolak dapat menyebabkan malapetaka, atau meyakini makanan tertentu memiliki kekuatan penarik terjadinya kemponan serta jappe' dilakukan karena ingin terhindar dari malapetaka.
Berdasarkan penelitian ini, terdapat beberapa saran yang diajukan penulis. Pertama, tradisi kemponan dan jappe' dalam masyarakat Melayu Sambas Kalimantan Barat perlu didefinisikan ulang sehingga penerapannya tidak bertentangan dengan ajaran Islam. Agar hal tersebut dapat dicapai, kemponan dapat diartikan sebagai terusmenerus kepikiran makanan yang ditawarkan. Adapun jappe' dapat diartikan sebagai penghormatan kepada orang yang menawarkan makanan, bukan sebagai penolak terjadinya malapetaka. Kedua, pendidikan dan pengetahuan masyarakat Melayu Sambas khususnya dalam masalah kemantapan akidah perlu ditingkatkan dengan berbagai upaya terutama memaksimalkan peran dai, guru, pemerintah (dalam hal ini Departemen Agama), dan kampus sehingga tradisi dan agama dapat berjalan selaras.

\section{References}

1. Afrizal. Metode Penelitian Kualitatif: Sebuah Upaya Mendukung Penggunaan Penelitian Kualitatif dalam Berbagai Disiplin Ilmu. Jakarta: PT. RajaGrafindo, 2016.

2. Ar. Wawancara. 2018.

3. As. Wawancara. 2018.

4. Az. Wawancara. 2018.

5. El. Wawancara. 2018.

6. Goddard C. Cultural values and 'cultural scripts' of Malay (Bahasa Melayu). Journal of Pragmatics 27: 183-201, 1997.

7. Gu. Wawancara. 2018.

8. H H. Wawancara. 2018.

9. Ju. Wawancara. 2018

10. K U. Wawancara. 2018.

11. Mn. Wawancara. 2018. 
12. Mustansyir R. Kearifan Lokal Masyarakat Melayu Sambas dalam Tinjauan Filosofis. Yogyakarta: Fakultas Filsafat Universitas Gajah Mada, 2015.

13. Nn. Wawancara. 2018.

14. Nindwihapsari NFN. Ungkapan Kemponan Dan Makna Simbolis Tentang Makanan Pada Masyarakat Kalimantan Barat (Kemponan Expression And Meaning Of Symbols On The Food Of The Peoples Of West Kalimantan). Kadera Bahasa 8: 219-227, 2016.

15. Nr. Wawancara. 2018.

16. Nu. Wawancara. 2018.

17. Posha BY, Sewang AM, Kara SAH, Siraj A. Peran Sultan Muhammad Mulia Ibrahim Syafiuddin di Kesultanan Sambas 1931-1943 Dalam Bidang Revitalisasi Lembaga Peradilan Agama. Jurnal Diskursus Islam 6: 175-200, 2018.

18. Prayogi A. Dinamika Identitas Budaya Melayu dalam Tinjauan Arkeo-Antropologis. TAMADDUN: Jurnal Kebudayaan dan Sastra Islam 16: 1-20, 2016.

19. R A. Wawancara. 2018.

20. Razi F. Tafsîr Fakhrurrâzi. Maktabah Syamilah, [date unknown].

21. Rn. Wawancara. 2018.

22. Ruhiyat R. Tradisi Sayyang Pattu'du di Mandar (Studi Kasus Desa Lapeo).
Jurnal Studi Agama dan Masyarakat 13: 1-26, 2017.

23. Sp. Wawancara. 2018.

24. Sugiyono. Metode Penelitian Kualitatif: untuk Penelitian yang bersifat eksploratif, enterpretif, interaktif, dan konstruktif. Bandung: CV. Alfabeta, 2017.

25. S J. Wawancara. 2018.

26. Widiastuti H. Pamali dalam Kehidupan Masyarakat Kecamatan Cigugur Kabupaten Kuningan (Kajian Semiotik dan Etnopedagogi). LOKABASA 6, 2015.

27. Yn. Wawancara. 2018.

28. Yusriadi Y. Identitas Dayak dan Melayu di Kalimantan Barat. Handep: Jurnal Sejarah dan Budaya 1: 1-16, 2019.

29. Yusuf Y. Studi Melayu. Jakarta: Wedatama Widya Sastra, 2009.

30. Sejarah Keraton Sambas [Online]. SEJARAH KERATON SAMBAS Peninggalan Sejarah Sambas: [date unknown]. http://smk-1telker.blogspot.com/p/sejarahkeraton-sambas.html [28 May 2019].

31. Kondisi Umum [Online]. [date unknown]. https://www.sambas.go.id/profiledaerah/pemerintahan/kondisiumum.html [29 May 2019]. 